\title{
IMPLEMENTASI METODE WEIGHTED PRODUCT DALAM SISTEM PENDUKUNG KEPUTUSAN PEMILIHAN LAYANAN UANG ELEKTRONIK TERBAIK
}

\author{
Melati Wasti ${ }^{1}$, Sari Hartini ${ }^{2}$, Rinawati $^{3}$ \\ Program Studi Sistem Informasi, STMIK Nusa Mandiri Jakarta \\ Jl. Damai No.8, Warung Jati Barat (Margasatwa), Jakarta Selatan \\ Telp.(021) 78839513 \\ melatiwasti@gmail.com sari.shi@nusamandiri.ac.id $\underline{\text { rinawati.riw@nusamandiri.ac.id }}$
}

\begin{abstract}
This research was conducted to assist users in choosing the best electronic money. Where electronic money is easier to use than conventional money. By using five criteria, namely: convenience, security, promotion, speed and convenience. This research was conducted on electronic money users in the city of Bekasi with a population of 3,013,851 people using a sample of 44 respondents. The method used is the weighted product method. The results of this study indicate that the first alternative electronic money recommendation obtained by OVO has a value of 0.391 with very positive criteria, namely convenience value $(K 1)=206$, security $(K 2)=204$, promotion $(K 3)=169$, speed $(K 4)=203$, convenience $(K 5)=183$. The second alternative electronic money recommendation obtained by Go-Pay has a value of 0.359 with criteria that have a very positive effect, namely convenience value $(K 1)=182$, security $(K 2)=168$, promotion $(K 3)=166$, speed $(K 4)=183$, comfort $(K 5)=$ 180. The third alternative recommendation for electronic money obtained by Dana has a value of 0.227 with criteria that have a very positive effect, namely convenience value $(K 1)=115$, security $(K 2)=126$, promotion $(K 3)=117$ speed $(K 4)=124$, comfort $(K 5)=111$.
\end{abstract}

\section{Keywords: Decision Support System, Electronic Money, Weighted Product Method}

\section{PENDAHULUAN}

Sebagian aktivitas yang kita lakukan beroperasi secara digital. Salah satunya masyarakat telah menyadari akan pentingnya alat tukar yang tidak bersifat fisik, baik kertas maupun logam, yaitu dengan alat tukar elektronik. Menurut Kim dalam (Quithbi, 2016) mengemukakan bahwa, "Alat tukar elektronik ini menjadi isu penting karena dianggap sebagai revolusi pembayaran masa depan yang akan menggantikan sistem tradisional berupa uang tunai dan cek".

Beberapa tahun belakangan ini, masyarakat Indonesia dikenalkan dengan instrumen pembayaran yang relatif baru untuk melakukan transaksi yang disebut dengan uang elektronik, ada dua bentuk uang elektronik yang dikenal yaitu server based dan chip based. Menurut Hidayat dalam (Usman, 2017) menyimpulkan bahwa:

Kemunculan uang elektronik merupakan jawaban atas kebutuhan terhadap instrumen pembayaran mikro yang diharapkan mampu melakukan proses pembayaran secara cepat dengan biaya yang relatif murah, karena pada umumnya nilai uang yang disimpan instrumen ini disimpan pada suatu tempat tertentu yang mampu diakses secara cepat, aman dan murah.

Permasalahan pengguna beralih alat tukar dari uang tunai menjadi uang elektonik karena alat tukar menggunakan uang elektronik bisa meningkatkan dalam efisiensi waktu, kemudahan, keamanan, berbagai promosi, menekan inflasi, menghindari pemalsuan uang yang beredar.

Dari ketiga sistem pembayaran yang menggunakan uang tradisional, uang tunai dan uang elektronik, pengguna lebih menyukai menggunakan sistem uang elektronik. Sistem pembayaran elektronik lebih unggul dalam enam alasan, yang terdiri dari kenyamanan $70 \%$, kecepatan pembayaran 59\%, keamanan dalam bertransaksi $46 \%$, kemudahan penggunaan $40 \%$, biaya transaksi rendah $38 \%$, serta berbagai penawaran dan promosi 35\% (Paypal, 2017).

Berdasarkan dari paparan yang telah diuraikan, didapatkan bahwa perlu diadakan penelitian untuk membantu para pengguna mengambil keputusan dalam memilih layanan uang elektronik terbaik, sehingga pengguna terhindar dari permasalahan-permasalahan yang sering timbul. Oleh sebab itu, penulis sangat tertarik dalam melakukan penelitian lebih lanjut mengenai layanan uang elektronik dengan metode Weighted Product.

Maksud yang ingin dicapai penulis dalam penelitian skripsi ini sebagai berikut:

1. Mengidentifikasi layanan uang elektronik sesuai kebutuhan pengguna.

2. Membuat penilaian pada setiap kriteria uang elektronik bagi pengguna. 
3. Menggunakan metode Weighted Product. dalam pemilihan uang elektronik terbaik.

Menurut (Fahmi, 2016) mengemukakan bahwa,"Definisi keputusan adalah proses penelusuran masalah yang berawal dari latar belakang, identifikasi masalah, hingga kepada terbentuknya kesimpulan atau rekomendasi. Rekomendasi itulah yang selanjutnya dipakai dan digunakan sebagai pedoman basis dalam pengambilan keputusan".

Menurut Litlle dalam (Sari, 2017) mengemukakan bahwa, "Sistem Pendukung Keputusan (SPK) adalah suatu sistem informasi yang menghasilkan berbagai alternatif keputusan untuk membantu manajemen dalam menangani berbagai permasalah". Adapun pengertian menurut (Reynolds, 2016) mengemukakan bahwa, "Sistem Pendukung Keputusan (SPK) menggunakan model analitik untuk membantu pengguna dalam mendapatkan wawasan terhadap situasi permasalahan, memeriksa solusi alternatif, dan merekomendasikan tindakan yang tepat".

Sistem Pendukung Keputusan (SPK) pertama kali diungkapkan pada tahun 1970 oleh Michael Scoot Morton.

Tujuan dari Sistem Pendukung Keputusan (SPK) menurut G.W Keen dan Scott Morton dalam (Nofriansyah \& Defit, 2017), yaitu:

1. Membantu manajer membuat keputusan untuk memecahkan masalah semi terstruktur.

2. Mendukung penilaian manajer bukan mencoba untuk menggantikannya.

3. Meningkatkan efektifitas pengambilan keputusan manajer dari pada efisiensinya.

Menurut (Sari, 2017) mengemukakan bahwa,"Metode Weighted Product merupakan teknik pengambilan keputusan dari beberapa pilihan alternatif yang ada. Metode ini memerlukan proses normalisasi pada perhitungannya”.

Menurut Kusumadewi dalam (Khairina, Ivando, \& Maharani, 2016) mengemukakan bahwa, "Metode Weighted Product merupakan metode untuk menyelesaikan Multi Attribute Decision Making (MADM), menggunakan teknik perkalian untuk menghubungkan peringkat atribut, dimana peringkat tiap atribut harus dipangkatkan terlebih dahulu dengan atribut bobot yang bersangkutan".

Langkah-langkah metode Weighted Product untuk menyelesaikan suatu permasalahan menggunakan multi kriteria, antara lain:

1. Menentukan kriteria yang akan dijadikan acuan dalam pengambilan keputusan.

2. Menentukan peringkat setiap alternatif pada setiap kriteria.

3. Menentukan bobot preferensi tiap kriteria.

Rumus untuk mengitung nilai bobot preferensi tiap kriteria, dinyatakan sebagai berikut:

$$
w_{j}=\frac{w_{j}}{\sum w_{j}}
$$

Keterangan :

Wj : bobot atribut

$\Sigma W j$ : jumlah keseluruhan nilai bobot.

4. Mengalikan seluruh atribut bagi sebuah alternatif dengan bobot sebagai pangkat positif untuk atribut keuntungan dan bobot berpangkat negatif untuk atribut biaya.

Rumus untuk menghitung nilai preferensi terhadap alternatif (Ai) dapat dinyatakan sebagai berikut:

$$
S_{i}=\prod_{j=1}^{n} x_{i j}{ }^{w j}
$$

Keterangan:

S : menyatakan preferensi alternatif yang dianologikan sebagai vektor $\mathrm{S}$

$\mathrm{x}$ : menyatakan nilai kriteria

w : menyatakan bobot kriteria

i : menyatakan alternatif

$\mathrm{j}$ : menyatakan kriteria

n : menyatakan banyaknya kriteria

5. Hasil perkalian tersebut dijumlahkan untuk menghasilkan nilai vektor $\mathrm{V}$ untuk setiap alternatif

Rumus untuk menghitung nilai vektor $\mathrm{V}$ dapat dihitung dengan rumus sebagai berikut:

$V_{i}=\frac{\prod_{j=1}^{n} x_{i j}{ }^{w j}}{\prod_{j=1}^{n}\left(x_{j}\right)^{w j}}$

\section{Keterangan:}

$\mathrm{V}$ : menyatakan preferensi alternatif yang dianalogikan sebagai vektor $\mathrm{V}$

$\mathrm{x}$ : menyatakan nilai kriteria

w : menyatakan bobot kriteria

i : menyatakan alternatif

$\mathrm{j}$ : menyatakan kriteria

$\mathrm{n}$ : menyatakan banyaknya kriteria

6. Mencari nilai alternatif dengan melakukan langkah yang sama seperti pada langkah satu, hanya saja menggunakan nilai tertinggi untuk setiap atribut tertinggi untuk setiap atribut manfaat dan nilai terendah untuk atribut biaya.

7. Membagi nilai $\mathrm{V}$ bagi setiap alternatif dengan nilai standar.

8. Mencari nilai alternatif ideal yakni dengan merangkai nilai vektor $\mathrm{V}$ sekaligus membuat kesimpulan sebagai tahap akhir.

Kelebihan Metode Weighted Product lebih spesifik langsung kepada bobot-bobot nilai di setiap kriterianya dan mudah untuk dilakukan perangkaiannya. Metode ini hampir sama seperti Metode Simple Additive Weighting. Kekurangannya sangat sederhana, karena tidak dilengkapi dengan kemampuan untuk mengurangi dan menambah model yang diperlukan untuk masalah yang lebih 
kompleks, sehingga kemungkinan kesalahan dalam pemilihan prioritas sangat tinggi (Sari, 2017).

\section{METODE}

Data-data yang terdapat pada penelitian ini dibuat dengan metode penelitian, sebagai berikut :

A. Observasi

Penelitian ini menggunakan metode observasi yang merupakan teknik pengumpulan data, dimana penulis melakukan pengamatan secara langsung kepada objek penelitian untuk melihat dari dekat kegiatan yang dilakukan. Observasi ini dilakukan pada pengguna uang eletronik.

B. Kuesioner

Metode kuesioner ini dilakukan melalui penyebaran kuesioner untuk diisi langsung oleh responden, yang terdiri dari pengguna yang memilih untuk menggunakan uang elektonik yang berada di Kota Bekasi dengan populasi berjumlah 3.013.851 jiwa dengan sampel menggunakan rumus slovin, yaitu :

$\mathrm{n}=\mathrm{N} /\left(1+\mathrm{N}\left(\mathrm{e}^{2}\right)\right)$

$\mathrm{n}=3.013 .851 /\left(1+3.013 .851\left(15 \%{ }^{2}\right)\right)$

$\mathrm{n}=44,39$ dibulatkan menjadi 44

C. Studi Pustaka

Metode studi pustaka adalah teknik pengumpulan yang dilakukan untuk menyusun landasan teoritis penelitian melalui sumber referensi dari buku, jurnal dan internet yang berkaitan dengan penelitian ini.

Tabel 1. Kisi-kisi Instrumen Penelitian

\begin{tabular}{|c|c|c|}
\hline Kniteria & Indikator Pemyataan & $\begin{array}{l}\text { Kniteria } \\
\text { Indikator }\end{array}$ \\
\hline \multirow{3}{*}{$\begin{array}{l}\text { Kemudahan } \\
\text { Aladwani dalam } \\
\text { (Sudjatmika, 2017) }\end{array}$} & Kemudahan untuk mencari, menemukan dan mengakses. & K1.1 \\
\hline & $\begin{array}{l}\text { Kemudahan untuk bergerak di satu halaman maupun } \\
\text { berpindah ke halaman lain. }\end{array}$ & K1.2 \\
\hline & $\begin{array}{l}\text { Kemudahan untuk mengisi format pembelian produk, } \\
\text { membeli produk, dan membatalkan pembelian. }\end{array}$ & $\mathrm{K} 1.3$ \\
\hline \multirow[t]{3}{*}{$\begin{array}{l}\text { Keamanan } \\
\text { (Sudjatmika, 2017) }\end{array}$} & $\begin{array}{l}\text { Kemampuan untuk menjamin kerahasiaan bahwa pesan- } \\
\text { pesan dan data yang tersedia. }\end{array}$ & K2.1 \\
\hline & $\begin{array}{l}\text { Kemampuan untuk melakukan pencegahan terhadap } \\
\text { modifikasi data yang tidak sah. }\end{array}$ & $\mathrm{K} 2.2$ \\
\hline & $\begin{array}{l}\text { Kemampuan untuk memberikan kontrol informasi pribadi } \\
\text { kepada pengguna. }\end{array}$ & $\mathrm{K} 2.3$ \\
\hline \multirow[t]{3}{*}{$\begin{array}{l}\text { Promosi } \\
\text { (Samosir \& K, 2015) }\end{array}$} & $\begin{array}{l}\text { Biasanya lebih menyukai produk yang memiliki potongan } \\
\text { harga. }\end{array}$ & K3.1 \\
\hline & Menawarkan potongan harga yang menarik perhatian. & $\mathrm{K} 3.2$ \\
\hline & $\begin{array}{l}\text { Adanya iklan di televisi membuat saya mengetahui atau } \\
\text { ingat kembali. }\end{array}$ & $\mathrm{K} 3.3$ \\
\hline \multirow[t]{3}{*}{$\begin{array}{l}\text { Kecepatan } \\
\text { (Sandi, 2018) }\end{array}$} & $\begin{array}{l}\text { Transaksi menggunakan digital dapat meminimalkan } \\
\text { waktu dibandingkan transaksi dengan konvensional. }\end{array}$ & $\mathrm{K} 4.1$ \\
\hline & $\begin{array}{l}\text { Tidak membutuhkan waktu yang relatif lama untuk } \\
\text { mendapatkannya. }\end{array}$ & $\mathrm{K} 4.2$ \\
\hline & $\begin{array}{l}\text { Tidak membutuhkan waktu atau proses lama untuk } \\
\text { mengklaim sisa saldo di dalamnya. }\end{array}$ & $\mathrm{K} 4.3$ \\
\hline \multirow{3}{*}{$\begin{array}{l}\text { Kenyamanan } \\
\text { Pranidana dalam } \\
\text { (Umar, 2015) }\end{array}$} & Dapat mengakses kapan pun dan dimana pun. & K5.1 \\
\hline & Tidak perlu mengantri. & $\mathrm{K} 5.2$ \\
\hline & Hemat waktujika dibandingkan dengan cara konvensional. & K5.3 \\
\hline
\end{tabular}

\section{PEMBAHASAN}

1) Gambaran Umum Responden

Responden adalah pengguna uang elektronik yang berada di kota Bekasi, secara keseluruhan jumlah sampel 44 responden dengan 15 pernyataan, memiliki 3 alternatif, yaitu Go-Pay (A1), OVO (A2), Dana (A3) dan memiliki 5 kriteria, yaitu kemudahan (K1), keamanan (K2), promosi (K3), kecepatan (K4), kenyamanan (K5).

Tabel 2. Jenis Kelamin Responden

\begin{tabular}{|c|c|c|}
\hline Jenis Kelamin & Jumlah Responden & Presentase \\
\hline Pria & 20 & $45,5 \%$ \\
\hline Wanita & 24 & $54,5 \%$ \\
\hline Total & 44 & $100 \%$ \\
\hline
\end{tabular}

Tabel 3. Domisili di kota Bekasi

\begin{tabular}{|c|c|c|}
\hline Domisili di kota Bekasi & Jumlah Responden & Presentase \\
\hline Pria & 20 & $45,5 \%$ \\
\hline Wanita & 24 & $54,5 \%$ \\
\hline Total & 44 & $100 \%$ \\
\hline
\end{tabular}

\section{2) Instrumen Penelitian}

\section{Tabel 4. Data Hasil Pernyataan Kuesioner}

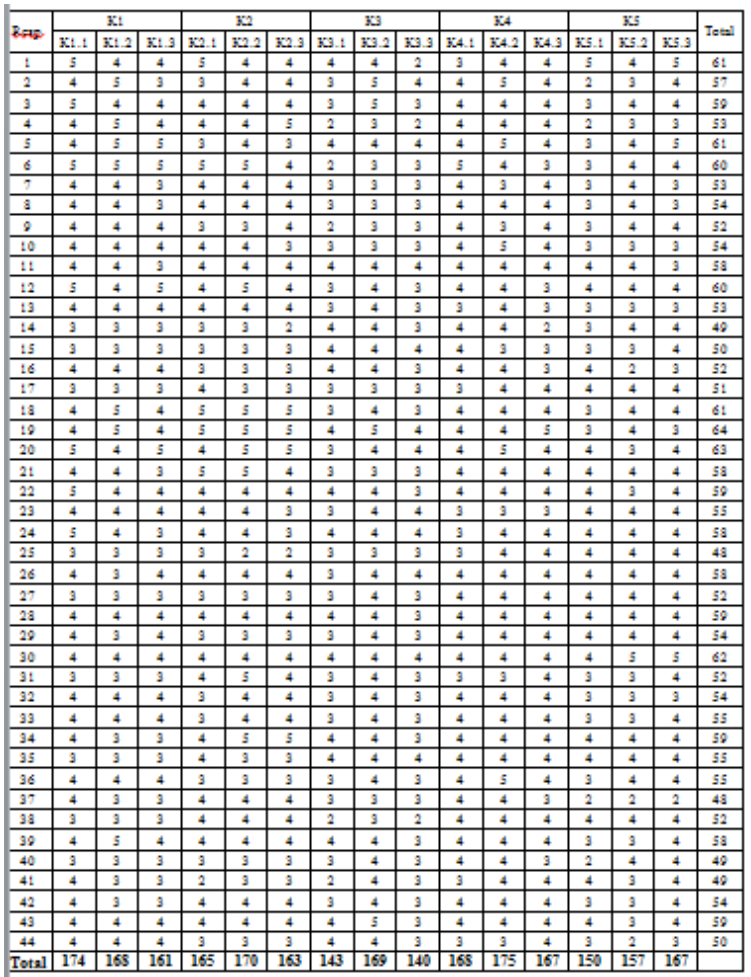

\section{3) Uji Validitas}

Menguji hasil validitas, yaitu jika $r$ hitung $\geq$ $r$ tabel 0,22 maka data dikatakan valid.

1. Berikut hasil uji validasi secara manual dengan rumus korelasi product moment pada pernyataan 1:

$$
\begin{aligned}
& r x y=N \Sigma X Y-(\Sigma X)(\Sigma Y) \\
& \quad \sqrt{\left\{N \Sigma X^{2}-(\Sigma X)^{2}\right\}\left\{N \Sigma Y^{2}-(\Sigma Y)\right\}^{2}} \\
& r x y=44 \times 9710-(174)(2437) \\
& \sqrt{\{44 \times 704-(30276)\}\{44 \times 135785-(5938969)\}} \\
& r x y=44 \times 9710-(424038)
\end{aligned}
$$




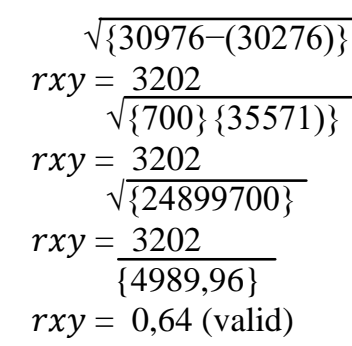

Tabel 5. Hasil Uji Validitas Excel

\begin{tabular}{|c|c|c|}
\hline R hirumg & R tabel & Keteraigan \\
\hline 0,64 & 0,22 & Valid \\
\hline 0,60 & 0,22 & Valid \\
\hline 0,57 & 0,22 & Valid \\
\hline 0,60 & 0,22 & Valid \\
\hline 0,70 & 0,22 & Valid \\
\hline 0,59 & 0,22 & Valid \\
\hline 0,32 & 0,22 & Valid \\
\hline 0,41 & 0,22 & Valid \\
\hline 0,32 & 0,22 & Valid \\
\hline 0,31 & 0,22 & Valid \\
\hline 0,35 & 0,22 & Valld \\
\hline 0,39 & 0,22 & Valid \\
\hline 0,30 & 0,22 & Valid \\
\hline 0,36 & 0,22 & Valid \\
\hline 0,37 & 0,22 & Valid \\
\hline
\end{tabular}

\section{Uji Reliabilitas}

Langkah-langkah uji reliabilitas $r$ hitung $\geq r$ tabel 0,70 maka data dikatakan Reliabel. Uji secara manual dengan menggunakan rumus Cronbach's Alpha pada pernyataan 1, sebagai berikut:

1. Mencari nilai Varian :

$$
\begin{aligned}
\alpha \mathrm{i}^{2} & =\left[\Sigma \mathrm{xi}^{2}-\left((\Sigma \mathrm{xi})^{2}: \mathrm{n}\right)\right]: \mathrm{n} \\
& =\left[704^{2}-\left((174)^{2}: 44\right)\right]: 44 \\
& =0,37
\end{aligned}
$$

2. Mencari nilai Jumlah Varian Skor:

$$
\begin{aligned}
\Sigma \alpha i^{2}= & 0,37+0,48+0,42+0,47+0,54+ \\
& 0,54+0,42+0,32+0,29+0,20+ \\
& 0,26+0,26+0,26+0,48+0,44+ \\
& 0,35=5,83
\end{aligned}
$$

3. Mencari nilai Varian Total :

$$
\begin{aligned}
\alpha \mathrm{T}^{2} & =\left[\Sigma \mathrm{yi}^{2}-\left((\Sigma \mathrm{yi})^{2}: \mathrm{n}\right)\right]: \mathrm{n} \\
& =\left[135785-\left((2437)^{2}: 44\right)\right]: 44 \\
& =18,80
\end{aligned}
$$

4. Mencari nilai Reabilitas :

$$
\begin{aligned}
\mathrm{r}_{11} & =[\mathrm{k}: \mathrm{k}-1]\left[1-\Sigma \alpha \mathrm{i}^{2}: \alpha \mathrm{T}^{2}\right] \\
& =[15: 15-1][1-5,83: 18,80] \\
& =0,74 \text { (reliabel) }
\end{aligned}
$$

Tabel 6. Hasil Uji Reliabilitas

\begin{tabular}{|c|c|c|c|c|c|}
\hline Varian & $\begin{array}{c}\text { Jumlah } \\
\text { Varian } \\
\text { Skor }\end{array}$ & $\begin{array}{c}\text { Varians } \\
\text { Total }\end{array}$ & Reliabilitas & R hitung & Keterangan \\
\hline 0,37 & 5,83 & 18,80 & 0,74 & 0,70 & Reliabel \\
\hline 0,48 & 5,83 & 18,80 & 0,74 & 0,70 & Reliabel \\
\hline 0,42 & 5,83 & 18,80 & 0,74 & 0,70 & Reliabel \\
\hline 0,47 & 5,83 & 18,80 & 0,74 & 0,70 & Reliabel \\
\hline 0,54 & 5,83 & 18,80 & 0,74 & 0,70 & Reliabel \\
\hline 0,54 & 5,83 & 18,80 & 0,74 & 0,70 & Reliabel \\
\hline 0,42 & 5,83 & 18,80 & 0,74 & 0,70 & Reliabel \\
\hline 0,32 & 5,83 & 18,80 & 0,74 & 0,70 & Reliabel \\
\hline 0,29 & 5,83 & 18,80 & 0,74 & 0,70 & Reliabel \\
\hline 0,20 & 5,83 & 18,80 & 0,74 & 0,70 & Reliabel \\
\hline 0,26 & 5,83 & 18,80 & 0,74 & 0,70 & Reliabel \\
\hline 0,26 & 5,83 & 18,80 & 0,74 & 0,70 & Reliabel \\
\hline 0,48 & 5,83 & 18,80 & 0,74 & 0,70 & Reliabel \\
\hline 0,44 & 5,83 & 18,80 & 0,74 & 0,70 & Reliabel \\
\hline 0,35 & 5,83 & 18,80 & 0,74 & 0,70 & Reliabel \\
\hline
\end{tabular}

\section{Pengujian Metode Weighted Product}

Setelah dilakukan uji validitas dan uji reliabilitas, kemudian data diolah ke metode weighted product yang mana dari ketiga uang elektronik perhitungannya akan dipisah.

Langkah-langkah untuk uji metode weighted product, yaitu sebagai berikut:

1. Menentukan nilai bobot setiap kriteria

Tabel 7. Nilai bobot setiap kriteria

\begin{tabular}{|c|c|}
\hline Kriteria Bobot & Jumlah Responden \\
\hline Kemudahan $\left(\mathrm{W}_{1}\right)$ & 9 \\
\hline Keamanan $\left(\mathrm{W}_{2}\right)$ & 9 \\
\hline Promosi $\left(\mathrm{W}_{3}\right)$ & 9 \\
\hline Kecepatan $\left(\mathrm{W}_{4}\right)$ & 9 \\
\hline Kenyamanan $\left(\mathrm{W}_{5}\right)$ & 8 \\
\hline
\end{tabular}

Rumus yang digunakan, yaitu:

$$
\begin{aligned}
& w_{j}=\frac{w_{j}}{\sum w_{j}} \\
& \mathrm{~W}_{1}=\frac{9}{9+9+9+9+8}=\frac{9}{44}=0,20 \\
& \mathrm{~W}_{2}=\frac{9}{9+9+9+9+8}=\frac{9}{44}=0,20 \\
& \mathrm{~W}_{3}=\frac{9}{9+9+9+9+8}=\frac{9}{44}=0,20 \\
& \mathrm{~W}_{4}=\frac{9}{9+9+9+9+8}=\frac{9}{44}=0,20 \\
& \mathrm{~W}_{5}=\frac{8}{9+9+9+9+8}=\frac{8}{44}=0,18
\end{aligned}
$$

2. Menentukan nilai kriteria: 
Tabel 8. Hasil Pernyataan Kuesioner Pengguna Go-Pay

\begin{tabular}{|c|c|c|c|c|c|c|c|c|c|c|c|c|c|c|c|c|}
\hline \multicolumn{17}{|c|}{ Go-Pay } \\
\hline \multirow{2}{*}{ Resp } & \multirow{2}{*}{\multicolumn{3}{|c|}{\begin{tabular}{l|l|l}
\multicolumn{3}{c}{ K1 } \\
K1. & K1. & K1
\end{tabular}}} & \multicolumn{3}{|c|}{\begin{tabular}{|l|l|}
\multicolumn{2}{|c|}{$\mathrm{K}_{2}$} \\
$\mathrm{~K} 2$ & $\mathrm{~K} 2$ \\
\end{tabular}} & & \multicolumn{3}{|c|}{ K4 } & \multicolumn{3}{|c|}{$\mathrm{K} 5$} & \multirow{2}{*}{ Total } \\
\hline & & & & $\begin{array}{l}\mathrm{K}_{2} \\
.1\end{array}$ & $\begin{array}{l}\mathrm{K} 2 \\
2\end{array}$ & ${ }_{3}^{\mathrm{K} 2}$. & $\begin{array}{l}\mathrm{K} 3 . \\
1\end{array}$ & & $\begin{array}{l}\text { K33 } \\
.3\end{array}$ & $\begin{array}{l}\text { K4 } \\
.1\end{array}$ & ${ }_{2}^{\mathrm{K} 4}$ & $\begin{array}{l}\text { K4 } \\
.3\end{array}$ & & $\begin{array}{l}\text { K5 } \\
.2\end{array}$ & $\begin{array}{l}\text { K5 } \\
.3\end{array}$ & \\
\hline 1 & 5 & 4 & 4 & 5 & 4 & 4 & 4 & 4 & 2 & 3 & 4 & 4 & 5 & 4 & 5 & 61 \\
\hline 5 & 4 & 5 & 5 & 3 & 4 & 3 & 4 & 4 & 4 & 4 & 5 & 4 & 3 & 4 & 5 & 61 \\
\hline 7 & 4 & 4 & 3 & 4 & 4 & 4 & 3 & 3 & 3 & 4 & 3 & 4 & 3 & 4 & 3 & 53 \\
\hline 8 & 4 & 4 & 3 & 4 & 4 & 4 & 3 & 3 & 3 & 4 & 4 & 4 & 3 & 4 & 3 & 54 \\
\hline 9 & 4 & 4 & 4 & 3 & 3 & 4 & 2 & 3 & 3 & 4 & 3 & 4 & 3 & 4 & 4 & 52 \\
\hline 12 & 5 & 4 & 5 & 4 & 5 & 4 & 3 & 4 & 3 & 4 & 4 & 3 & 4 & 4 & 4 & 60 \\
\hline 15 & 3 & 3 & 3 & 3 & 3 & 3 & 4 & 4 & 4 & 4 & 3 & 3 & 3 & 3 & 4 & 50 \\
\hline 16 & 4 & 4 & 4 & 3 & 3 & 3 & 4 & 4 & 3 & 4 & 4 & 3 & 4 & 2 & 3 & 52 \\
\hline 24 & 5 & 4 & 3 & 4 & 4 & 3 & 4 & 4 & 4 & 3 & 4 & 4 & 4 & 4 & 4 & 58 \\
\hline 25 & 3 & 3 & 3 & 3 & 2 & 2 & 3 & 3 & 3 & 3 & 4 & 4 & 4 & 4 & 4 & 48 \\
\hline 27 & 3 & 3 & 3 & 3 & 3 & 3 & 3 & 4 & 3 & 4 & 4 & 4 & 4 & 4 & 4 & 52 \\
\hline 30 & 4 & 4 & 4 & 4 & 4 & 4 & 4 & 4 & 4 & 4 & 4 & 4 & 4 & 5 & 5 & 62 \\
\hline 32 & 4 & 4 & 4 & 3 & 4 & 4 & 3 & 4 & 3 & 4 & 4 & 4 & 3 & 3 & 3 & 54 \\
\hline 35 & 3 & 3 & 3 & 4 & 3 & 3 & 4 & 4 & 4 & 4 & 4 & 4 & 4 & 4 & 4 & 55 \\
\hline 39 & 4 & 5 & 4 & 4 & 4 & 4 & 4 & 4 & 3 & 4 & 4 & 4 & 3 & 3 & 4 & 58 \\
\hline 41 & 4 & 3 & 3 & 2 & 3 & 3 & 2 & 4 & 3 & 3 & 4 & 4 & 4 & 3 & 4 & 49 \\
\hline & 63 & 61 & 58 & 56 & 57 & 55 & & & 52 & 60 & 62 & 61 & 58 & 59 & 63 & \\
\hline
\end{tabular}

Tabel 9. Hasil Kriteria Go-Pay

\begin{tabular}{|c|c|c|c|c|c|}
\hline & K1 & K2 & K3 & K4 & K5 \\
\hline $\begin{array}{c}\text { Total Kriteria } \\
\text { Go-Pay }\end{array}$ & 182 & 168 & 166 & 183 & 180 \\
\hline
\end{tabular}

Berdasarkan hasil tabel perhitungan di atas, Go-Pay memiliki hasil nilai untuk masing-masing kriteria, yaitu kemudahan $(\mathrm{K} 1)=182$, keamanan $(\mathrm{K} 2)=168$, promosi $(\mathrm{K} 3)=166$, kecepatan $(\mathrm{K} 4)=$ 183 , kenyamanan $(\mathrm{K} 5)=180$.

Tabel 10. Hasil Pernyataan Kuesioner Pengguna OVO

\begin{tabular}{|c|c|c|c|c|c|c|c|c|c|c|c|c|c|c|c|c|}
\hline \multicolumn{17}{|c|}{ ovo } \\
\hline \multirow[b]{2}{*}{ Resp } & \multicolumn{3}{|c|}{$\mathrm{K} 1$} & \multicolumn{3}{|c|}{$\mathrm{K} 2$} & \multicolumn{3}{|c|}{$\mathrm{K} 3$} & \multicolumn{3}{|c|}{$\mathrm{K} 4$} & \multicolumn{3}{|c|}{$\mathrm{K} 5$} & \multirow[b]{2}{*}{ Total } \\
\hline & $\begin{array}{l}\mathrm{K} 1 \\
.1 \\
\end{array}$ & $\begin{array}{l}\mathrm{K} 1 \\
.2 \\
\end{array}$ & $\begin{array}{l}\mathrm{K} 1 \\
.3 \\
\end{array}$ & $\begin{array}{l}\mathrm{K} 2 \\
.1\end{array}$ & $\begin{array}{l}\mathrm{K} 2 \\
.2 \\
\end{array}$ & $\begin{array}{l}\mathrm{K} 2 \\
.3\end{array}$ & \begin{tabular}{|l}
$\mathrm{K} 3$ \\
.1 \\
\end{tabular} & $\begin{array}{l}\text { K3 } \\
.2 \\
\end{array}$ & \begin{tabular}{|l}
$\mathrm{K} 3$ \\
.3 \\
\end{tabular} & \begin{tabular}{|l|} 
K4 \\
. \\
\end{tabular} & \begin{tabular}{|l} 
K4 \\
.2 \\
\end{tabular} & \begin{tabular}{|l|}
$\mathrm{K} 4$ \\
.3 \\
\end{tabular} & \begin{tabular}{|l} 
K5 \\
1 \\
\end{tabular} & $\begin{array}{l}\mathrm{K} 5 \\
.2 \\
\end{array}$ & $\begin{array}{l}\mathrm{K} 5 \\
3 \\
\end{array}$ & \\
\hline 2 & 4 & 5 & 3 & 3 & 4 & 4 & 3 & 5 & 4 & 4 & 5 & 4 & 2 & 3 & 4 & 57 \\
\hline 3 & 5 & 4 & 4 & 4 & 4 & 4 & 3 & 5 & 3 & 4 & 4 & 4 & 3 & 4 & 4 & 59 \\
\hline 4 & 4 & 5 & 4 & 4 & 4 & 5 & 2 & 3 & 2 & 4 & 4 & 4 & 2 & 3 & 3 & 53 \\
\hline 6 & 5 & 5 & 5 & 5 & 5 & 4 & 2 & 3 & 3 & 5 & 4 & 3 & 3 & 4 & 4 & 60 \\
\hline 10 & 4 & 4 & 4 & 4 & 4 & 3 & 3 & 3 & 3 & 4 & 5 & 4 & 3 & 3 & 3 & 54 \\
\hline 13 & 4 & 4 & 4 & 4 & 4 & 4 & 3 & 4 & 3 & 3 & 4 & 3 & 3 & 3 & \begin{tabular}{|l|}
3 \\
\end{tabular} & 53 \\
\hline 18 & 4 & 5 & 4 & 5 & 5 & 5 & 3 & 4 & 3 & 4 & 4 & 4 & 3 & 4 & 4 & 61 \\
\hline 20 & 5 & 4 & 5 & 4 & 5 & 5 & 3 & 4 & 4 & 4 & 5 & 4 & 4 & 3 & 4 & 63 \\
\hline 21 & 4 & 4 & 3 & 5 & 5 & 4 & 3 & 3 & 3 & 4 & 4 & 4 & 4 & 4 & 4 & 58 \\
\hline 23 & 4 & 4 & 4 & 4 & 4 & 3 & 3 & 4 & 4 & 3 & 3 & 3 & 4 & 4 & 4 & 55 \\
\hline 26 & 4 & 3 & 4 & 4 & 4 & 4 & 3 & 4 & 4 & 4 & 4 & 4 & 4 & 4 & 4 & 58 \\
\hline 28 & 4 & 4 & 4 & 4 & 4 & 4 & 4 & 4 & 3 & 4 & 4 & 4 & 4 & 4 & 4 & 59 \\
\hline 29 & 4 & 3 & 4 & 3 & 3 & 3 & 3 & 4 & 3 & 4 & 4 & 4 & 4 & 4 & 4 & 54 \\
\hline 33 & 4 & 4 & 4 & 3 & 4 & 4 & 3 & 4 & 3 & 4 & 4 & 4 & 3 & 3 & 4 & 55 \\
\hline 36 & 4 & 4 & 4 & 3 & 3 & 3 & 3 & 4 & 3 & 4 & 5 & 4 & 3 & 4 & 4 & 55 \\
\hline 38 & 3 & 3 & 3 & 4 & 4 & 4 & 2 & 3 & 2 & 4 & 4 & 4 & 4 & 4 & 4 & 52 \\
\hline 43 & 4 & 4 & 4 & 4 & 4 & 4 & 4 & 5 & 3 & 4 & 4 & 4 & 4 & 3 & \begin{tabular}{|l|}
4 \\
\end{tabular} & 59 \\
\hline & 70 & 69 & 67 & \begin{tabular}{|l|}
67 \\
\end{tabular} & 70 & 67 & 50 & 66 & 53 & 67 & 71 & 65 & 57 & \begin{tabular}{|l|}
61 \\
\end{tabular} & 65 & \\
\hline
\end{tabular}

Tabel 11. Hasil Kriteria OVO

\begin{tabular}{|c|c|c|c|c|c|}
\hline & K1 & K2 & K3 & K4 & K5 \\
\hline $\begin{array}{c}\text { Total Kriteria } \\
\text { OV0 }\end{array}$ & 206 & 204 & 169 & 203 & 183 \\
\hline
\end{tabular}

Berdasarkan hasil tabel perhitungan di atas, OVO memiliki hasil nilai untuk masing-masing kriteria, yaitu kemudahan $(\mathrm{K} 1)=206$, keamanan
$(\mathrm{K} 2)=204$, promosi $(\mathrm{K} 3)=169$, kecepatan $(\mathrm{K} 4)=$ 203 , kenyamanan $(\mathrm{K} 5)=183$.

Tabel 12. Hasil Pernyataan Kuesioner Pengguna Dana

\begin{tabular}{|c|c|c|c|c|c|c|c|c|c|c|c|c|c|c|c|c|}
\hline \multicolumn{17}{|c|}{ Dana } \\
\hline \multirow[b]{2}{*}{ Resp } & \multicolumn{3}{|c|}{$\mathrm{K} 1$} & \multicolumn{3}{|c|}{$\mathrm{K} 2$} & \multicolumn{3}{|c|}{$\mathrm{K}_{3}$} & \multicolumn{3}{|c|}{$\mathrm{K} 4$} & \multicolumn{3}{|c|}{$\mathrm{K} 5$} & \multirow[b]{2}{*}{ Total } \\
\hline & $\begin{array}{l}\mathrm{K} 1 . \\
1\end{array}$ & K1 & $\begin{array}{l}\mathrm{K} 1 \\
.3\end{array}$ & $\begin{array}{l}\mathrm{K} 2 \\
.1\end{array}$ & $\frac{\mathrm{K}_{2}}{2}$ & $\begin{array}{l}\mathrm{K} 2 \\
.3\end{array}$ & $\begin{array}{l}\mathrm{K} 3 \\
.1\end{array}$ & $\begin{array}{l}\mathrm{K} 3 \\
.2\end{array}$ & $\begin{array}{l}\mathrm{K} 3 \\
.3\end{array}$ & $\begin{array}{l}\mathrm{K} 4 \\
1 .\end{array}$ & $\begin{array}{l}\mathrm{K} 4 \\
.2\end{array}$ & \begin{tabular}{|l|}
$\mathrm{K} 4$ \\
3
\end{tabular} & $\begin{array}{l}\mathrm{K} 5 \\
.1\end{array}$ & $\begin{array}{l}\mathrm{K} 5 \\
.2\end{array}$ & $\begin{array}{l}\mathrm{K} 5 \\
3\end{array}$ & \\
\hline 11 & 4 & 4 & 3 & 4 & 4 & 4 & 4 & 4 & 4 & 4 & 4 & \begin{tabular}{|l|}
4 \\
\end{tabular} & 4 & 4 & 3 & 58 \\
\hline 14 & 3 & 3 & 3 & 3 & 3 & 2 & 4 & 4 & 3 & 4 & 4 & 2 & 3 & 4 & 4 & 49 \\
\hline 17 & 3 & 3 & 3 & 4 & 3 & 3 & 3 & 3 & 3 & 3 & 4 & 4 & 4 & 4 & 4 & 51 \\
\hline 19 & 4 & 5 & 4 & 5 & 5 & 5 & 4 & 5 & 4 & 4 & 4 & 5 & \begin{tabular}{|l|}
3 \\
\end{tabular} & \begin{tabular}{|l|} 
\\
\end{tabular} & 3 & 64 \\
\hline 22 & 5 & 4 & 4 & 4 & 4 & 4 & 4 & 4 & 3 & 4 & 4 & \begin{tabular}{|l|}
4 \\
\end{tabular} & 4 & 3 & 4 & 59 \\
\hline 31 & 3 & 3 & 3 & 4 & 5 & 4 & 3 & 4 & 3 & 3 & 3 & $\begin{array}{ll} \\
\end{array}$ & 3 & 3 & 4 & 52 \\
\hline 34 & 4 & 3 & 3 & 4 & 5 & 5 & 4 & 4 & 3 & 4 & \begin{tabular}{|l|}
4 \\
\end{tabular} & \begin{tabular}{|l|}
4 \\
\end{tabular} & 4 & 4 & 4 & 59 \\
\hline 37 & 4 & 3 & 3 & 4 & 4 & 4 & 3 & 3 & 3 & 4 & 4 & 3 & 2 & 2 & 2 & 48 \\
\hline 40 & 3 & 3 & 3 & 3 & 3 & 3 & 3 & 4 & 3 & 4 & 4 & 3 & 2 & 4 & 4 & 49 \\
\hline 42 & 4 & 3 & 3 & 4 & 4 & 4 & 3 & 4 & 3 & 4 & 4 & 4 & 3 & 3 & 4 & 54 \\
\hline 44 & 4 & 4 & 4 & 3 & 3 & 3 & 4 & 4 & 3 & 3 & 3 & 4 & 3 & 2 & 3 & 50 \\
\hline & 41 & 38 & 36 & 42 & 43 & 41 & 39 & 43 & 35 & 41 & 42 & \begin{tabular}{|l|}
41 \\
\end{tabular} & 35 & \begin{tabular}{|l|}
37 \\
\end{tabular} & 39 & \\
\hline
\end{tabular}

Tabel 13. Hasil Kriteria Dana

\begin{tabular}{|c|c|c|c|c|c|}
\hline & K1 & K2 & K3 & K4 & K5 \\
\hline $\begin{array}{c}\text { Total Kriteria } \\
\text { Dara }\end{array}$ & 115 & 126 & 117 & 124 & 111 \\
\hline
\end{tabular}

Berdasarkan hasil tabel perhitungan di atas, Dana memiliki hasil nilai untuk masing-masing kriteria, yaitu kemudahan $(\mathrm{K} 1)=115$, keamanan $(\mathrm{K} 2)=126$, promosi $(\mathrm{K} 3)=117$ kecepatan $(\mathrm{K} 4)=$ 124 , kenyamanan $(\mathrm{K} 5)=111$.

3. Menentukan Vektor S, yaitu dengan rumus:

$$
\begin{aligned}
S_{i}= & \prod_{j=1}^{n} x_{i j}{ }^{w j} \\
\mathrm{~S}_{1}= & \left(182^{.0,20}\right)\left(168^{.0,20}\right)\left(166^{.0,20}\right)\left(183^{.0,20}\right) \\
& \left(180^{.0,18}\right) \\
= & (2,83)(2,78)(2,77)(2,83)(2,54) \\
= & 156,650 \\
\mathrm{~S}_{2} \quad & \left(206^{.0,20}\right)\left(204^{.0,20}\right)\left(169^{.0,20}\right)\left(203^{.0,20}\right) \\
& \left(183^{.0,18}\right) \\
= & (2,90)(2,89)(2,78)(2,89)(2,55) \\
= & 171,703 \\
= & \left(115^{.0,20}\right)\left(126^{.0,20}\right)\left(117^{.0,20}\right)\left(124^{.0,20}\right) \\
& \left(111^{.0,18}\right) \\
= & (2,58)(2,63)(2,59)(2,62)(2,33) \\
= & 107,283
\end{aligned}
$$

Tabel 14. Hasil Nilai Vektor $S$

\begin{tabular}{|c|c|}
\hline $\begin{array}{c}\text { Uang Elektronik } \\
\text { Alternatif }\end{array}$ & Vektor S \\
\hline Go-Pay (A1) & 156,650 \\
\hline OVO (A2) & 171,703 \\
\hline Dana (A3) & 107,283 \\
\hline
\end{tabular}

Berdasarkan hasil tabel perhitungan di atas, maka hasil nilai vektor $S$ untuk masing-masing uang elektronik alternatif, yaitu Go-Pay memiliki nilai 156,650 , OVO 171,703 , dan Dana 107,283. 
4. Menentukan Vektor $\mathrm{V}$, yaitu dengan rumus :

$$
\begin{aligned}
& V_{i}=\frac{\prod_{j=1}^{n} x_{i j}{ }^{w j}}{\prod_{j=1}^{n}\left(x_{j}\right)^{w j}} \\
& \mathrm{~V}_{1}=\frac{156,650}{156,650+171,703+107,283}=\frac{156,650}{435,636} \\
& =0,359 \\
& \mathrm{~V}_{2}=\frac{171,703}{156,650+171,703+107,283}=\frac{=171,703}{435,636} \\
& =0,394 \\
& \mathrm{~V}_{3}=\frac{98,966}{156,650+171,703+107,283}=\frac{98,996}{435,636} \\
& =0,227
\end{aligned}
$$

\section{Tabel 15. Hasil Nilai Vektor V}

\begin{tabular}{|c|c|c|}
\hline Peringkat Alternatif & $\begin{array}{c}\text { Uang Elektronik } \\
\text { Alternatif }\end{array}$ & $\begin{array}{c}\text { Nilai Akhir } \\
\text { (Vektor V) }\end{array}$ \\
\hline 2 & Go-Pay (A1) & 0,359 \\
\hline 1 & OVO (A2) & 0,394 \\
\hline 3 & Dana (A3) & 0,227 \\
\hline
\end{tabular}

Dari hasil nilai vektor $\mathrm{V}$ yang diperoleh di atas, maka peringkat rekomendasi alternatif yang memiliki nilai tertinggi yaitu OVO dengan nilai 0,394 , yang memiliki nilai kedua yaitu Go-Pay dengan nilai 0,359 dan yang memiliki nilai terendah yaitu Dana dengan nilai 0,227.

\section{KESIMPULAN}

Berdasarkan hasil penelitian yang telah dilakukan tentang implementasi metode weighted product dalam sistem pendukung keputusan pemilihan layanan uang elektronik terbaik dapat diambil kesimpulan bahwa:

1. Rekomendasi alternatif uang elektronik yang pertama diperoleh oleh OVO memiliki nilai 0,394 dengan kriteria yang sangat berpengaruh positif yaitu nilai kemudahan $(\mathrm{K} 1)=206$, keamanan $(\mathrm{K} 2)=204$, promosi $(\mathrm{K} 3)=169$, kecepatan $(\mathrm{K} 4)=203$, kenyamanan $(\mathrm{K} 5)=183$.

2. Rekomendasi alternatif uang elektronik yang kedua diperoleh oleh Go-Pay memiliki nilai 0,359 dengan kriteria yang sangat berpengaruh positif yaitu nilai kemudahan $(\mathrm{K} 1)=182$, keamanan $(\mathrm{K} 2)=168$, promosi $(\mathrm{K} 3)=166$, kecepatan $(\mathrm{K} 4)=183$, kenyamanan $(\mathrm{K} 5)=180$.

3. Rekomendasi alternatif uang elektronik yang ketiga diperoleh oleh Dana memiliki nilai 0,227 dengan kriteria yang sangat berpengaruh positif yaitu nilai kemudahan $(\mathrm{K} 1)=115$, keamanan $(\mathrm{K} 2)=126$, promosi $(\mathrm{K} 3)=117$ kecepatan $(\mathrm{K} 4)=124$, kenyamanan $(\mathrm{K} 5)=111$

\section{PUSTAKA}

Bank Indonesia. (2018). Peraturan Bank Indonesia tentang Uang Elektronik, 4-5. Retrieved from https://www.bi.go.id/id/peraturan/sistempembayaran/Pages/PBI-200618.aspx April 2019)

Fahmi, I. (2016). Teori dan Teknik Pengambilan Keputusan Kualitatif dan Kuantitatif. (M. A. Djalil, Ed.) (2nd ed.). Depok: PT RajaGrafindo Persada.

Hikmah, A. B., \& Wiguna, W. (2018). Sistem Penunjang Keputusan Penilaian Kinerja Kasir Lotte Mart Menggunakan Metode Weighted Product, 3(2), 186-196. (30 April 2019)

Khafiyah, N. N. (2019). Pengaruh Persepsi Mahasiswa Mengenai Uang Elektronik Terhadap Minat Menggunakan Aplikasi OVO. Retrieved from http://jurnal.iicet.org/index.php/jppi/article/vi ew/182/211 (28 April 2019)

Khairina, D. M., Ivando, D., \& Maharani, S. (2016). Implementasi Metode Weighted Product Untuk Aplikasi Pemilihan Smartphone Android, 8(1), 1-8. Retrieved from http://ejournal.st3telkom.ac.id/index.php/infot el/article/view/47 (28 April 2019)

Nofriansyah, D., \& Defit, S. (2017). Multi Criteria Decision Making (MCDM) pada Sistem Pendukung Keputusan. (H. Rahmandhani \& C. M. Sartono, Eds.) (Pertama). Yogyakarta: CV Budi Utama.

Quthbi, Z. H. (2016). 27 Keputusan Menggunakan E Money. Pengaruh Kemudahan, Manfaat, Keamanan dan Privasi. Retrieved from https://gilib.uinsuka.ac.id/20129/2/12390013_BAB1_IV_atau-V_DAFTAR-PUSTAKA.pdf (09 April 2019)

Samosir, C. B. H., \& K, A. B. P. (2015). Pengaruh Persepsi Harga dan Promosi Terhadap Keputusan Pembelian Konsumen Produk ENERVON-C. Jurnal Ilmiah Manajemen Dan Bisnis, 1(3), 267-422. Retrieved from https://media.neliti.com/media/publications/9 6826-ID-jurnal-pengaruh-persepsi-harga-danpromo.pdf\%0A (28 Mei 2019)

Sandi, M. (2018). Kuesioner Penggunaan Kartu EMoney Bank Mandiri, 3(September). Retrieved from http://eprints.umpo.ac.id/4042/8/LAMPIRAN 
.pdf (28 Mei 2019)

Sari, F. (2017). Metode dalam Pengambilan Keputusan. (D. Novidiantoko \& H. A. Susanto, Eds.) (Pertama). Yogyakarta: CV Budi Utama.

Sodik, S. S. \& A. (2015). Dasar Metodologi Penelitian (1st ed.). Yogyakarta: Literasi Media Publishing.

Sudaryono. (2018). Metodologi Penelitian. Depok: PT RajaGrafindo Persada.

Sudjatmika, F. V. (2017). Pengaruh Harga, Ulasan Produk, Kemudahan, dan Keamanan terhadap Keputusan Pembelian secara Online di Tokopedia.com, 5(1). (29 Mei 2019)

Umar, F. (2015). Pengaruh kenyamanan, kepercayaan, dan kelengkapan fitur terhadap keputusan penggunaan, Vol 5 No 1, 1-10. Retrieved from http://ejournal.umpwr.ac.id/index.php/segmen /article/download/3960/3725 (29 Mei 2019)

Umar, H. (2019). Metode Riset Manajemen Perusahaan. (I. Febrianto \& Fajarianto, Eds.) (1st ed.). Jakarta: PT Gramedia Pustaka Utama.

Usman, R. (2017). Karakteristik Uang Elektronik Dalam Sistem Pembayaran. Yuridika, 32(1), 134. https://doi.org/10.20473/ydk.v32i1.4431 (08 April 2019)

Wardhani, S. (2018). Menuju Masyarakat tanpa Uang Tunai. Retrieved from https://www.validnews.id/MENUJU-

MASYARAKAT-TANPA-UANG-TUNAIAMn (08 April 2019) 